\title{
PELATIHAN MITIGASI BENCANA ALAM GEMPA BUMI PADA SISWA SEKOLAH DASAR NEGERI 1 PENGASTULAN KECAMATAN SERIRIT KABUPATEN BULELENG BALI
}

\author{
I Wayan Subagia ${ }^{1}$, I G. L. Wiratma², I Ketut Sudita ${ }^{3}$ \\ 1,2,3 Universitas Pendidikan Ganesha \\ Email: aigabus@yahoo.co.id
}

\begin{abstract}
Abstrak
Gempa bumi merupakan salah satu peristiwa alam yang belum bisa diramalkan kejadiannya dan dapat menimbulkan kerugian material hingga merenggut korban nyawa manusia. Oleh karena itu, peristiwa gemba bumi perlu diinformasikan kepada seluruh lapisan masyarakat, terutama kepada siswa sekolah dasasr (SD). Penelitian ini merupakan implementasi kurikulum Mitigasi Bencana Alam Gempa Bumi (MBAGB) yang bertujuan untuk memberikan pelatihan MBAGB kepada siswa SD dan mengidentifikasi permasalahan-permasalahan yang muncul dalam pelatihan. Dalam penelitian ini, dilibatkan sebanyak 55 orang siswa SD yang terdiri atas siswa kelas IV dan kelas V. Hasil penelitian ini menunjukkan bahwa para siswa mengikuti pembelajaran secara sungguh-sungguh, baik dalam bentuk mendengarkan informasi yang diberikan maupun dalam latihan-latihan yang dipraktikan. Namun demikian, mereka mengalami hambatan dalam mengerjakan tes tertulis. Banyak siswa belum bisa memahami pertanyaan yang diberikan dan belum mampu mengomunikasikan pemahaman dan pengetahuannya secara tertulis. Berdasarkan temuan tersebut, disarankan agar di SD proses pembelajaran membaca, menulis, dan menalar perlu ditingkatkan sesuai dengan tuntutan kurikulum.
\end{abstract}

Kata kunci: pelatihan, mitigasi, gempa bumi, sekolah dasar.

\begin{abstract}
Earthquake is one of natural phenomena that cannot be predicted and may cause disaster for human life. Therefore, Earthquake is important to be informed to all people, especially to elementary school children. This research is the implementation of earthquake mitigation curriculum aimed to give training of earthquake disaster mitigation to elementary school children and identify problems existing along the training. This research involved 55 elementary students of grade IV and $\mathrm{V}$. The research result revealed that the children were able to follow the training seriously, both in listening information as well as doing pratical exercises. However, there were some problems faced by the student in doing test. Many
\end{abstract}


students were not able to understand the given question and they could not communicate their understanding and knowledge through writing. Based on this finding, it is suggested that in elmentary school, the process of learning how to read, write, and understand text critically needs to be improved in accordance with curriculum requirement.

Keywords: training, mitigation, earthquake, elementary school.

\section{PENDAHULUAN}

Gempa bumi merupakan peristiwa alam yang waktu dan tempat kejadiannya belum bisa diprediksi. Walaupun gempa bumi rentan terjadi di daerah lingkaran api (ring of fire), namun di bagian mana dan kapan akan terjadi belum dapat ditentukan secara ilmiah. Secara umum, wilayah kepulauan Indonesia sebagian besar terletak di daerah lingkaran api yang terbentang dari Pulau Sumatera, Jawa, Bali, Nusa Tenggara, Sulawesi, Maluku, sampai dengan Papua (Departemen Energi dan Sumber Daya Mineral, tt). Oleh karena itu, dapat dinyatakan bahwa daerah-daerah yang ada di wilayah Negara Kesatuan Republik Indonesia rawan terhadap bahaya gempa bumi. Hal tersebut dibuktikan dengan beberapa kejadian gempa bumi besar maupun kecil yang terjadi di masa lalu, seperti gempa yang terjadi di daerah Sumatera pada tahun 2004, gempa yang terjadi di Yogyakarta pada tahun 2006, dan gempa yang terjadi di Bali pada tahun 1976 dan 1979 (Lilik Kurniawan, dkk. 2011).

Kejadian gempa bumi, selain menimbulkan kerugian material berupa bangunan, ternak, dan pertanian, juga dapat menimbulkan korban nyawa manusia. Kejadian gempa bumi yang hingga menelan korban jiwa disebut dengan bencana gempa bumi. Kejadian gempa bumi yang disampaikan di atas, hampir semuanya menelan korban jiwa manusia di samping harta benda. Oleh karena itu, kejadian-kejadian tersebut dikenal dengan bencana gempa bumi. Korban jiwa yang ditimbulkan ketika kejadian gempa bumi tidak semata-mata disebabkan oleh gempa itu sendiri, namun sering dipicu oleh kejadian lain yang menyertainya, seperti tsunami, tanah longsor, dan banjir. Contoh, gempa bumi yang terjadi di Aceh pada tahu 2004 menelan ratusan ribu jiwa akibat dari tsunami yang terjadi sebagai rangkaian gempa bumi.

Dengan mengtahui bahwa kejadian gempa bumi belum bisa diguga secara ilmiah, perlu dilakukan usaha untuk mengurangi risiko akibat yang ditibulkan gempa bumi. Usaha-usaha yang dilakukan untuk mengurangi risiko gempa bumi disebut Mitigasi Bencana Alam Gempa Bumi (MBAGB) (Subagia dan Wiratma, 2013; 2012). Pada penelitian ini, dilakukan pelatihan MBAGB bagi siswa SD Negeri 1 Pengastulan Kecamatan Seririt 
Kabupaten Buleleng Provinsi Bali dengan tujuan untuk meningkatkan pengetahuan dan keterampilan mereka dalam menghadapi ancaman bahaya gempa bumi. Dalam pelatihan ini, diimplementasikan kurikulum pendidikan MBAGB yang diformulasikan dengan memadukan antara pengetahuan kegempaan dengan pengetahuan dan pengamalam masyarakat Bali dalam menghadapi kejadian gemba bumi. Pengetahuan dan pengalaman masyarakat Bali yang telah diwariskan secara turun-temurun untuk mengurasi risiko kejadian gempa bumi didefinisikan sebagai kearifan lokal masyarakat Bali dalam MBAGB (Subagia dan Wiratma, 2013; 2012).

Ada berbagai bentuk kearifan local masyarakat Bali yang relevan dengan kajian kejadian gempa bumi yang berhasil diidentifikasi dan diformulasikan dalam penelitian ini yang dikelompokkan menjadi dua, yaitu pemberitahuan kejadian gempa kepada orang lain dan pemberitahuan keadaan diri sendiri pada saat terjadi gempa. Ketika terjadi gempa masyarakat Bali umumnya berteriak linuh, linuh, linuh, yang artinya terjadi gempa. Teriakan tersebut disampaikan kepada orang lain yang ada di sekitarnya untuk mengingatkan bahwa telah terjadi gempa. Diharapkan setiap orang yang menyadari telah terjadi gempa segera melakukan tindakan penyelamatan sesuai dengan keadaan setempat. Di samping berteriak, masyarakat juga memukul benda-benda yang mengeluarkan bunyi, umumnya kentongan, untuk mengingatkan bahwa telah terjadi gempa kepada anggota masyarakat lain yang ada di kejauhan atau yang sedang ada di dalam rumah. Untuk memberitahuan keadaan dirinya, masyarakat Bali, umumnya, berteriak hidup, hidup, hidup, yang artinya dalam kejadian tersebut mereka masih hidup atau memohon kepada Tuhan Yang Maha Esa agar tetap hidup. Bentuk pemberitahuan diri tersebut, biasanya, digunakan apabila gempa terjadi pada malam hari. Ketika gempa terjadi pada malam hari, biasanya, lampu penerangan padam dan suasana menjadi gelap gulita. Pada saat seperti itu, sangat sulit untuk menemukan sanak saudara. Apabila kebiasaan berteriak seperti itu (hidup, hudup, hidup) disampaikan oleh setiap orang, maka dengan mudah dikenali mereka yang ada dalam bahaya, yaitu mereka yang tidak berteriak (Subagia dan Wiratma, 2013; 2012).

Penggunaan kearifan lokal dalam mitagasi bencana alam telah banyak digunakan oleh masyarakat. Joko Martono (2011) menyatakan bahwa memahami budaya lokal di daerah rawan bencana merupakan alternatif yang sangat masuk akal untuk mengurangi risiko bencana. Salah satu kebiasaan masyarakat yang bisa dirujuk adalah kebiasaan masyarakat di kepualuan Semeulue. Masyarakat di kepulauan Semeulue terbiasa berteriak smong ketika air laut surut secara tibatiba karena hal itu dipahami sebagai Jurnal Pendidikan Indonesia/ 587 
pertanda akan terjadi "ombak besar" yang dikenal dengan tsunami. Pada saat terjadi tsunami Aceh, tahun 2004, yang menelan ratusan ribu korban nyama manusia, masyarakat di kepulauan Semeulue hampir tidak ada yang menjadi korban karena ketika air laut surut secara tiba-tiba masyarakat berteriak smong diikuti dengan perilaku lari ke daerah yang lebih tinggi.

Untuk memberikan pemahaman dan pelatihan kepada masyarakat, khususnya siswa SD tentang gempa bumi dan akibatnya, disusunlah kurikulum pendidikan MBAGB melaui penelitian pengembangan (research and development). Secara garis besar, hasil penelitian pengembangan kurikulum tersebut berisikan rumusan Standar Kompetensi (SK), Kompetensi Dasar (KD), dan Indikator Pencapaian Kompetensi (IPK) yang dapat dijadikan pandulan pembelajaran atau pelatihan. Rumusan SK, KD, dan IPK adalah sebagai berikut.

Tabel 1. SK, KD, dan IPK Kurikulum Pendidikan Mitigasi Bencana Alam Gempa Bumi

\begin{tabular}{|c|c|c|}
\hline $\begin{array}{c}\text { Standar } \\
\text { Kompetensi }\end{array}$ & Kompetensi Dasar & Indikator Pencapaian Kompetensi \\
\hline $\begin{array}{l}\text { 1. Memahami } \\
\text { hakikat } \\
\text { gempa bumi. }\end{array}$ & $\begin{array}{l}\text { 1. } 1 \text { Mendeskripsikan } \\
\text { hakikat gempa bumi. }\end{array}$ & $\begin{array}{ll}\text { - } & \text { Mendefinisikan gempa bumi. } \\
\text { - } & \text { Menggambarkan peristiwa akibat gempa } \\
\text { bumi. } & \\
\text { - } & \text { Menjelaskan peristiwa gempa bumi. }\end{array}$ \\
\hline $\begin{array}{l}\text { 2. Memahami } \\
\text { akibat yang } \\
\text { ditimbulkan } \\
\text { oleh gempa } \\
\text { bumi. } \\
\end{array}$ & $\begin{array}{l}\text { 2.1 Mendeskripsikan } \\
\text { akibat yang } \\
\text { ditimbukan oleh } \\
\text { gempa bumi }\end{array}$ & $\begin{array}{ll}\text { - } & \text { Mengidentifikasi akibat gempa bumi. } \\
\text { - } & \text { Mengelompokkan akibat gempa bumi. } \\
\text { - } & \text { Menjelaskan akibat gempa bumi. }\end{array}$ \\
\hline \multirow[t]{2}{*}{$\begin{array}{l}\text { 3. Memahami } \\
\text { cara-cara } \\
\text { mitigasi } \\
\text { bencana } \\
\text { alam gempa } \\
\text { bumi. }\end{array}$} & $\begin{array}{l}\text { 3.1 Mendeskripsika cara- } \\
\text { cara penyelamatan } \\
\text { diri pada saat gempa } \\
\text { bumi. }\end{array}$ & $\begin{array}{l}\text { - } \quad \text { Mengidentifikasi cara penyelamatan diri } \\
\text { ketika gempa bumi. } \\
\text { - Menjelaskan cara-cara penyelamatan diri } \\
\text { ketika gempa bumi. } \\
\text { - Melakukan latihan menyelamatkan diri } \\
\text { ketika gempa bumi }\end{array}$ \\
\hline & $\begin{array}{l}\text { 3.2 Mendeskripsikan } \\
\text { cara-cara } \\
\text { mengantisipasi } \\
\text { bencana alam gempa } \\
\text { bumi }\end{array}$ & $\begin{array}{l}\text { - Mengidentifikasi cara-cara } \\
\text { mengantisipasi bencana alam gempa } \\
\text { bumi. } \\
\text { - Menjelaskan cara-cara mengantisipasi } \\
\text { bencana alam gempa bumi. } \\
\text { - Menggambarkan peta evakuasi. } \\
\text { - Membuat model antisipasi penyelamatan } \\
\text { diri pada saat gempa bumi. }\end{array}$ \\
\hline
\end{tabular}

Selain dalam bentuk deskripsi SK, KD, dan IPK, kurikulum pendidikan
MBAGB juga dilengkapi dengan urain materi pelatihan, cara pelaksanaan 
pelatihan atau pembelajaran, dan cara penilaian kemampuan siswa dalam mengikuti pelatihan atau pembelajaran. Materi pembelajaran atau pelatihan terdiri atas materi teoretis berupa pemahaman siswa terhadap hakikat gempa bumi, cara melakukan mitigasi, dan cara membatu masyarakat yang mengalami penderitaan ringan, serta materi praktik berupa cara melakukan mitigasi diri dan orang lain, serta cara memberikan pertolongan pertama kepada korban (Subagia dan Wiratma, 2013; 2012).

\section{METODE}

Secara keseluruhan, penelitian ini dilaksanakan melalui metode penelitian dan pengembangan yang dilakukan dalam beberapa tahap, yaitu tahap explorasi, formulasi, dan examinasi. Penelitian ini merupakan tahapan examinasi dalam bentuk uji empirik terbatas kurikulum pendidikan MBAGB yang diformulasikan sebelumnya dan telah diujikan melalui uji ahli (expert judgment). Dalam penelitian ini dilibatkan 55 orang siswa SDN 1 Pengastulan Kecamatan Seririt Kabupaten Buleleng Provinsi Bali yang terdiri atas siswa kelas IV dan kelas V. Pelatihan MBAGB dilakukan selama dua hari dengan perincian kegiatan sebagai berikut. Pertama, siswa diajak berdiskusi tentang kajadian gempa bumi, dilanjutkan dengan kegiatan menggambar peristiwa yang terjadi saat terjadi gempa bumi, dan diakhiri dengan kegiatan menjelaskan gambar yang dibuat di depan kelas. Kedua, siswa diajak berdiskusi tentang akibat dari gempa bumi, dilanjutkan dengan kegiatan menggambar berbagai peristiwa akibat gempa bumi, dan diakhiri dengan kegiatan menjelaskan gambar yang dibuat di depan kelas. Ketiga, siswa diajak untuk berdiskusi tentang cara mengamankan diri ketika terjadi gempa bumi disertai dengan latihan penyelamatan diri dan melakukan pertolongan pertama kepada penderita korban. Keempat, siswa diajak berdiskusi tentang tempat-tempat yang aman untuk berlingdung ketika terjadi gempa bumi dan diakhiri dengan membuat peta evakuasi di sekolah serta menjelaskan peta evakuasi yang dibuat di depan kelas. Terakhir, setelah semua kegiatan selesai, siswa diberikan tes tertulis dalam bentuk isian singkat.

Seluruh kegiatan pelatihan dipandu dengan unit-unit pembelajaran. Ada lima unit pembelajaran yang disispakan pelatihan MBAGB, yaitu: 1) Hakikat Gempa Bumi, 2) Akibat Gempa Bumi, 3) Cara Penyelematan Diri Saat Terjadi Gempa Bumi, 4) Cara Mengantisipasi Gempa Bumi, dan 5) Model Antisipasi Gempa Bumi. Kearifan lokal masyarakat Bali dalam MBAGB menjadi bagian isi dari unit-uniit pembelajaran yang diberikan. Pada pelatihan ini, hanya empat unit yang disampaikan. Unit terakhir, yaitu Model Antisipasi Gempa Bumi belum didiskusikan karena masalah teknik di lapangan. 
Salah satu contoh unit pembelajaran yang digunakan adalah sebagai berikut.

\section{UNIT 1: HAKIKAT GEMPA BUMI}

Identitas Materi Pelatihan

a. Nama materi : Mitigasi Bencana Alam Gempa Bumi

b. Topik : Hakikat Gempa Bumi

: Siswa SD kelas

c. Sasaran

d. Waktu : 90 menit.

Tujuan Pelatihan

a. Siswa mampu mendefinisikan peristiwa gempa bumi melalui diskusi kelas.

b. Siswa mampu menggambarkan berbagai peristiwa akibat kejadian gempa bumi melalui gambar yang dibuat secara individu di atas kertas gambar.

c. Siswa mampu menjelaskan peristiwa gempa bumi melalui gambar yang dibuat di hadapan kelompok.

Uraian Materi Pelatihan

Pengertian gempa bumi: gempa bumi adalah getaran yang berasal dari dalam bumi yang disebabkan oleh peristiwa yang terjadi di dalam perut bumi.

Contohnya adalah aktivittas gunung api, runtuhan dalam rongga perut bumi, dan pergeseran lempengan bumi.

Gempa bumi dapat diklasifikasikan menjadi dua, yaitu gempa vulkanik yang disebabkan oleh aktivitas gunung api dan gempa tektonik yang disebabkan oleh runtuhan dalam rongga bumi atau pergeseran lempengan bumi.

Peristiwa gempa bumi dapat diwujudkan melalui gambar, antara lain: gambar rumah roboh, tanah longsor, bendungan jebol, jalan putus, banjir, pohon tumbang, lampu padam, masyarakat panik, dan lain-lain yang relevan.

Peristiwa gempa bumi: terjadi tanpa ada peringatan dini, dapat terjadi pada siang atau malam hari, dapat terjadi di darat maupun di laut, dan menimbulkan kerugian materi hingga korban jiwa.

Tahapan Kegiatan Pelatihan

\author{
Alat dan bahan yang diperlukan \\ 1. Buku gambar \\ 2. Pensil \\ 3. Pensil warna (krayon) \\ 4. Dobel tips \\ 5. Media gambar
}

\section{Pendekatan $/$ metode}

Kegiatan pelatihan menggunakan pendekatan partisipatif yang mengajak siswa secara aktif berpartisipasi dalam pelatihan melalui mendengarkan informasi, memberi tanggapan (respons), menggambarkan peristiwa, dan mempresentasikan ide atau pemahamannya melalui gambar. 


\section{Langkah-langkah kegiatan}

\begin{tabular}{|c|c|c|}
\hline Tahapan & Kegitan Pelatihan & Waktu \\
\hline $\begin{array}{l}\text { Kegiatan } \\
\text { Awal }\end{array}$ & $\begin{array}{l}\text { Pelatih/guru memberi apersepsi materi dengan menanyakan } \\
\text { kepada peserta pelatihan berbagai kejadian gempa bumi } \\
\text { yang diketahui. }\end{array}$ & 5 menit \\
\hline \multirow[t]{6}{*}{$\begin{array}{l}\text { Kegiatan } \\
\text { Inti }\end{array}$} & 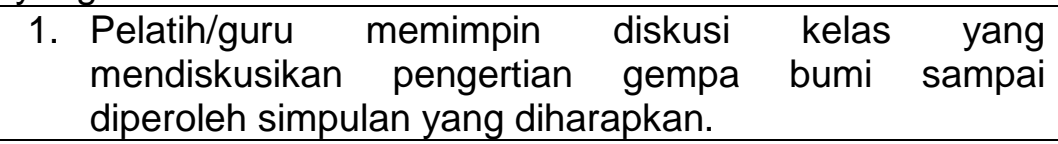 & 15 menit \\
\hline & $\begin{array}{l}\text { 2. Pelatih/guru membagikan alat-alat menggambar kepada } \\
\text { peserta pelatihan dan meminta setiap peserta untuk } \\
\text { menggambarkan kejadian gempa bumi secara individu }\end{array}$ & 20 menit \\
\hline & $\begin{array}{l}\text { 3. Pelatih/guru meminta siswa membentuk kelompok (3 - } \\
5 \text { orang) dan setiap anggota kelompok diminta untuk } \\
\text { menjelaskan gambarnya kepada teman-temannya. }\end{array}$ & $\begin{array}{l}10-15 \\
\text { menit }\end{array}$ \\
\hline & $\begin{array}{l}\text { 4. Pelatih/guru meminta kelompok untuk memilih gambar } \\
\text { terbaik dalam kelompokknya dan wakil kelompok untuk } \\
\text { menjelaskan gambar tersebut di depan kelas. }\end{array}$ & $\begin{array}{l}10-15 \\
\text { menit }\end{array}$ \\
\hline & $\begin{array}{l}\text { 5. Pelatih/guru meminta siswa untuk menempelkan } \\
\text { gambarnya di depan kelas dan meminta semua siswa } \\
\text { untuk memilih tiga gambar terbaik dari gambar yang } \\
\text { ada. }\end{array}$ & 5 menit \\
\hline & $\begin{array}{l}\text { 6. Pelatih/guru menyampaikan apresiasi kepada siswa } \\
\text { atas partisipasinya dan memberikan penghargaan } \\
\text { terhadap semua gambar terpilih yang ditempelkan di } \\
\text { depan kelas sebagai bentuk penilaian. }\end{array}$ & 5 menit \\
\hline $\begin{array}{l}\text { Kegiatan } \\
\text { Akhir }\end{array}$ & $\begin{array}{l}\text { Pelatih/guru menutup pelajaran dengan mengajak semua } \\
\text { siswa untuk merangkum hasil kegiatan belajar yang terdiri } \\
\text { atas: pengertian gempa bumi dan kejadian lain yang } \\
\text { disebabkan oleh kajadian gempa bumi sebagai catatan } \\
\text { siswa. }\end{array}$ & 10 menit \\
\hline
\end{tabular}

Penilaian Hasil Kegiatan Pelatihan

Penilaian hasil kegiatan pelatihan dilakukan dalam dua bentuk, yaitu penilaian partisipasi selama kegiatan dan penilaian penguasaan materi di akhir pelatihan. Penilaian partisipasi dilakukan melalui pengamatan, sedangkan penilaian penguasaan materi dilakukan melalui tes tertulis. Pedoman pengamatan partisipasi dan tes penguasaan materi disediakan secara terpisah.

Hasil penilaian partisipasi dalam kegiatan dituliskan dalam bentuk deskripsi dengan kategori sebagai berikut. 
Berpartisipasi cukup, apabila peserta pelatihan mengikuti pelatihan secara penuh (dengan simbol +).

Berpartisipasi baik, apabila peserta pelatihan mengikuti pelatihan secara penuh dan sesekali memberi tanggapan (bertanya atau menjawab) terhadap materi yang disampaikan (dengan simbol ++).

Berpartisipasi sangat baik, apabila peserta pelatihan mengikuti pelatihan secara penuh dan beberapa kali memberi tanggapan (bertanya atau menjawab) terhadap materi pelatihan (dengan simbol +++ .

Hasil penilaian penguasaan materi ditetapkan dengan penilaian acuan patokan (PAP) dalam skala 100 dengan kategori sebagai berikut:

$\begin{array}{ll}\text { Sangat kurang } & =0-20 \% \\ \text { Kurang } & =21-40 \% \\ \text { Cukup } & =41-60 \% \\ \text { Baik } & =61-80 \% \\ \text { Sangat baik } & =81-100 \%\end{array}$

(Sumber: Subagia, Wiratma, dan Sudita, 2014)

\section{HASIL DAN PEMBAHASAN}

Sesuai dengan isi materi pelatihan, hasil penelitian ini dapat dikelompokkan menjadi dua, yaitu deskripsi kualitatif hasil pelaksanaan pelatihan dan deskripsi kuantitatif pencapaian hasil tes penguasaan materi.

1) Deskripsi hasil pelaksanaan pelatihan

Secara umum, semua siswa yang berjumlah 55 orang mengikuti pelaksanaan pelatihan secara sungguhsungguh, baik dalam mendengarkan informasi maupun dalam melakukan praktik-praktik yang diberikan. Materi pendidikan dan pelatihan yang disampaikan ada empat, yaitu hakikat gempa bumi, akibat yang ditimbukan, cara penyelamatan diri saat terjadi gempa bumi, dan cara mengantisipasi kejadian gempa bumi. Informasi disampaikan dengan metode diskusi kelas dan tanya jawab. Praktik-praktik yang dilakukan selama pelatihan terdiri atas pelatihan menggambar berbagai peristiwa yang terkait dengan gempa bumi, melakukan mitigasi di dalam kelas, ke luar kelas, dan di luar kelas, serta praktik memberikan pertolongan pertama kepada penderita korban.

Di awal kegiatan, siswa terlihat sedikit tegang karena berhadapan dengan orang baru (pelatih) sehingga pelatih (peneliti) perlu beberapa saat untuk melakukan penyesuaian diri. Siswa tidak mau menjawab pertanyaanpertanyaan yang disampaikan walaupun yang sederhana. Keadaan tersebut lalu dipecahkan dengan memberikan motivasi berupa hadiah kepada siswa yang mau menjawab pertanyaan yang disampaikan pelatih. Hadiah-hadiah yang diberikan berupa alat-alat Jurnal Pendidikan Indonesia/592 
pelajaran sederhana, seperti penggaris, pengapus, pensil, dan pulpen yang disiapkan sebagai bahan-bahan pelatihan. Hal tersebut ternyata mampu mencairkan suasana dan siswa mulai mau berpartisipasi dalam merespon pertanyaan-pertanyaan yang diberikan. Jawaban-jawaban yang diberikan siswa banyak yang belum sempurna. Hal ini menunjukkan bahwa mereka belum lancar berkomunikasi dalam Bahasa Indonesia.

Pada saat kegiatan praktik menggambar peristiwa yang terjadi saat gempa bumi, banyak siswa tidak punya ide tentang gambar yang mesti dibuat. Setelah diberi contoh peristiwa yang terjadi, mereka mulai aktif menggambar sesuai dengan idenya dan mewarnai gambarnya dengan pewarna yang telah disediakan. Namun, tidak semua siswa mampu menuangkan idenya dengan baik ke dalam bentuk gambar. Beberapa gambar yang dibuat terlihat kurang jelas dan tidak diwarnai secara penuh. Namun demikian, siswa terlihat sangat antusias dalam melakukan kegiatan tersebut.

Setelah mereka selesai menggambar, mereka disuruh membentuk kelompok kecil yang terdiri atas 5 - 6 orang. Dalam kelompok tersebut mereka diminta untuk menceritakan gambar mereka masingmasing kepada teman-temannya dan mimilih gambar terbaik yang akan digunakan sebagai gambar yang mewakili kelompoknya untuk dipresentasikan di depan kelas. Kegiatan tersebut semuanya dapat diikuti dengan baik sehingga diperoleh gambar yang dipilih sebagai wakil kelompoknya.

Pada saat presentasi, setiap wakil kelompok diminta untuk menceritakan gambar yang telah dibuat di depan kelas. Lagi-lagi ditemukan bahwa tidak semua siswa yang mewakili kelompoknya mampu mengomunikasikan gambarnya dengan baik. Tampak bahwa siswa mengalami masalah dalam berkomunikasi secara lisan dalam Bahasa Indonesia. Setelah dibantu secara bertahap, akhirnya semua kelompok menyelesaikan tugas presentasinya dengan baik dengan bahasa sederhana.

Kegiatan-kegiatan tersebut dilakukan dengan cara yang sama untuk tiga materi pendidikan dan pelatihan lainnya, yaitu akibat gempa bumi, cara penyelamatan diri saat gempa bumi, dan cara mengantisipasi gempa bumi. Berikut ini adalah gambar-gambar yang dibuat siswa pada saat pelatihan. 


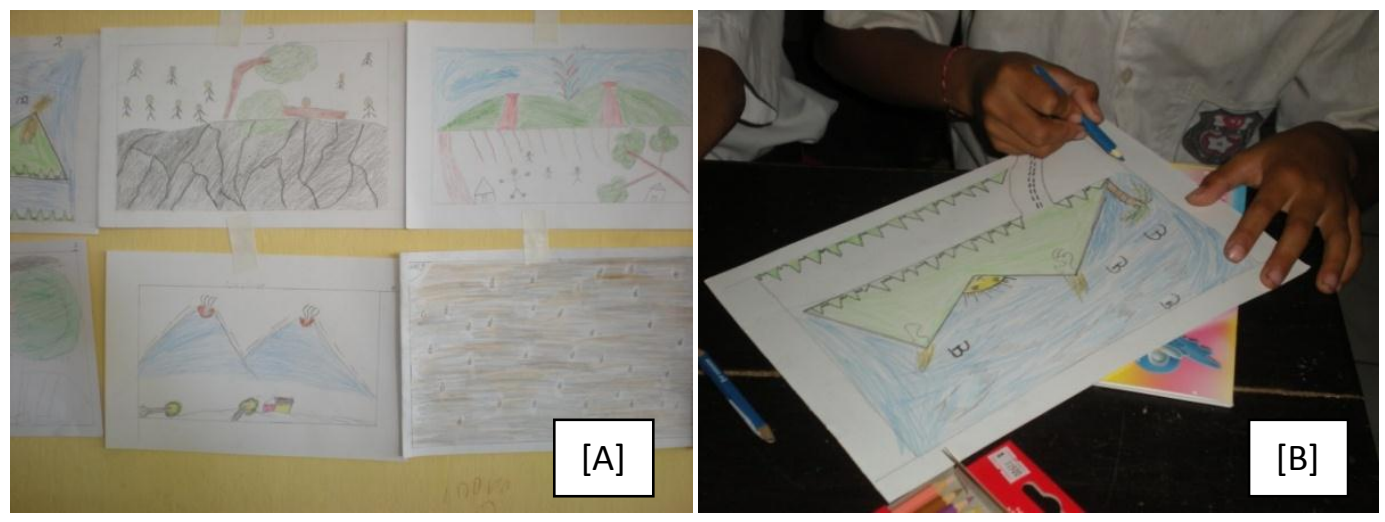

Keterangan foto: [A] gambar peristiwa gemba bumi, dan [B] siswa sedang menggambar.

Selain menggambar, kegiatan praktik yang diberikan dalam pelatihan adalah praktik penyelamatan diri di dalam kelas, ke luar kelas, dan di luar kelas, serta praktik memberikan pertolongan pertama kepada korban dalam bentuk memberikan obat merah dan membalut luka. Seluruh kegiatan praktik dapat diikuti dengan baik oleh seluruh siswa. Tampak bahwa sebagian besar siswa sudah memiliki pengetahuan untuk penyelamatan diri ketika terjadi gempa. Hal tersebut dapat dilihat dari kecepatan mereka menerima dan mengikuti petunjuk yang diberikan.
Misalnya, ketika mereka dilatih untuk berlindung di bawah meja saat terjadi gempa, dalam waktu singkat mereka bisa melakukannya dengan baik.

Dalam praktik pemberikan pertolongan kepada korban yang dilakukan dalam bentuk pemberian obat merah dan membalut luka, terlihat beberapa siswa masih menunjukkan keraguan untuk melakukannya. Namun dengan bimbingan pelatih, mereka mampu melakukannya dengan baik. Kegiatan praktik yang dilaksakan oleh para siswa direkam dalam bentuk foto yang disajikan sebagai berikut.
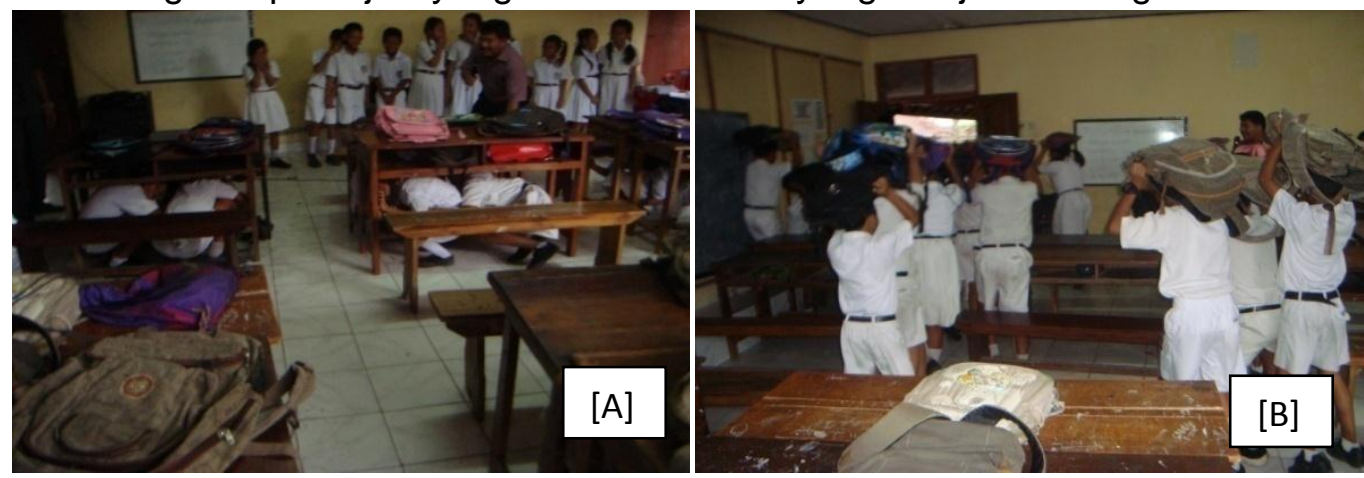

Jurnal Pendidikan Indonesia/594 


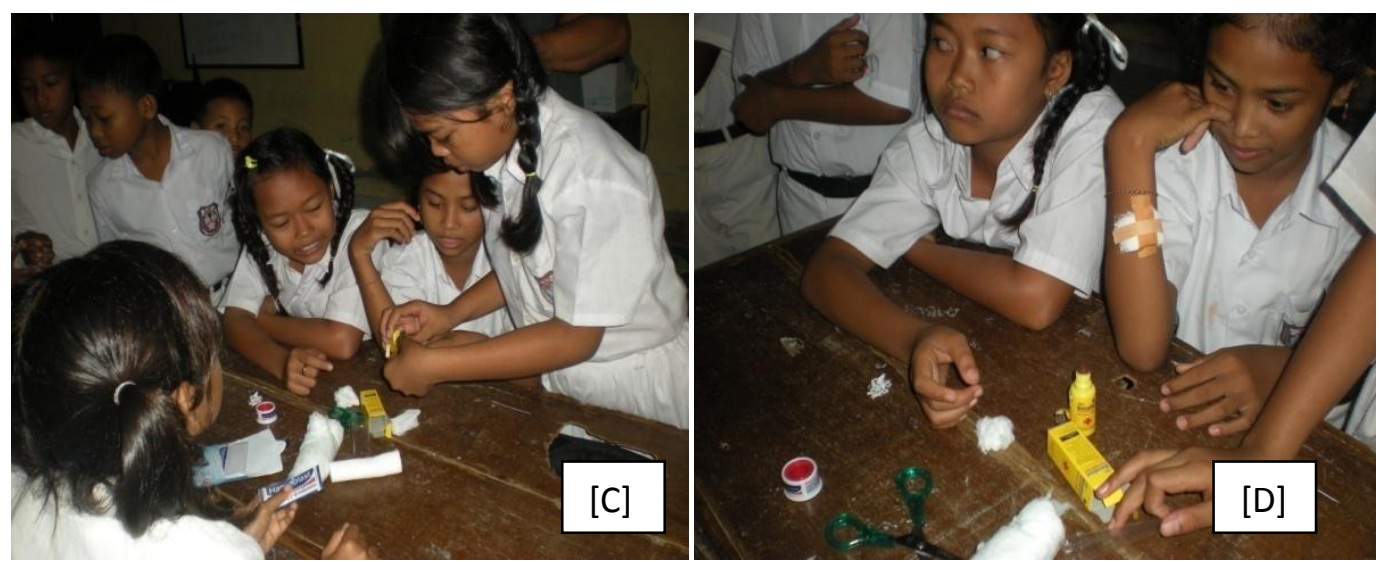

Keterangan foto: $[\mathrm{A}]$ siswa latihan berlindung di bawah bangku, [B] siswa ke luar kelas, [C] siswa membalut luka, dan [D] hasil balutan luka siswa.

2) Deskripsi pencapaian hasil tes

Selain diamati secara langsung, penguasaan siswa terhadap materi pelatihan juga dikumpulkan melalui tes tertulis dalam bentuk isian singkat yang diberikan di akhir kegiatan. Pertanyaan/permintaan yang diberikan dalam tes tertulis adalah sebanyak 10 buah, yaitu: 1) Apakah yang dimaksud dengan gempa bumi? 2) Apakah yang dimaksud dengan gempa vulkanik? 3) Apakah yang dimaksud dengan gempa tektonik? 4) Tuliskan tiga peristiwa yang umumnya terjadi saat gempa bumi! 5)
Tuliskan lima contoh peristiwa akibat gempa bumi! 6) Tuliskan tiga contoh perilaku penyelamatan diri ketika terjadi gempa bumi! 7) Tukliskan tiga cara untuk mengantisipasi kejadian gempa! 8) Tuliskan tiga hal yang mesti dilakukan setelah terjadi gempa bumi! 9) Jelaskan apa yang dimaksud dengan peta evakuasi! 10) Jelaskan mengapa perlu peta evakuasi!

Hasil tes yang diperoleh disajikan dalam bentuk diagram pie dalam skala 100 sebagi berikut.

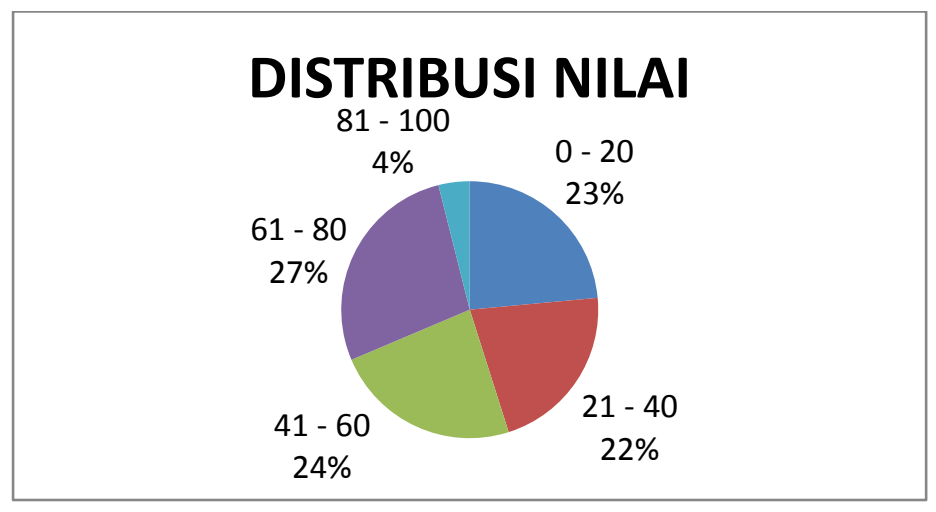

Jurnal Pendidikan Indonesia/595 
Berdasarkan diagram pie di atas, dapat dilihat bahwa 4\% siswa memperoleh nilai dengan kategori sangat baik (81 $100) ; 27 \%$ siswa memperoleh nilai dengan kategori baik (61 - 80), 24\% memperoleh nilai dengan kategori cukup (41 - 60), 22\% memperoleh nilai dengan kategori kurang $(21$ - 40), dan $23 \%$ memperoleh nilai dengan kategori sangat kurang $(0-20)$. Oleh karena itu, dapat dinyatakan bahwa lebih dari 55\% siswa yang mengikuti pembelajaran selama dua hari telah mampu menunjukkan pemahamannya terhadap materi bencana alam gempa bumi dengan kategori cukup hingga sangat baik dan sisanya (45\%) dengan terkategori kurang hingga sangat kurang. Capaian ini menunjukkan bahwa materi yang diberikan memberi harapan baik untuk meningkatkan pemahaman siswa terhadap bencana alam gempa bumi dan cara-cara melakukan mitigasi gempa bumi sehingga risikonya dapat diminimalkan.

Pelaksanaan pelatihan MBAGB yang dilaksanakan di SDN 1 Pengastulan Kecamatan Seririt Kabupaten Buleleng Provinsi Bali berjalan dengan baik. Namun demikian, hasil dari pelaksanaan pelatihan tersebut tampak belum optimal. Beberapa permasalahan yang dipandang perlu untuk dipecahkan agar pelaksanaan pelatihan MBAGB di sekolah-sekolah dapat berjalan optimal adalah kesiapan SDM (guru) pemandu MBAGB, kesiapan prasarana dan sarana di sekolah, dan kesiapan pengetahuan siswa dalam baca tulis. Dyah Respati Suryo Sumunar, seorang peneliti dan sekaligus dosen Jurusan Pendidikan Geografi Universitas Negeri Yogyakarta, menyatakan bahwa kendala dalam melakukan pengurangan resiko bencana di sekolah adalah pengetahuan dan kemampuan guru, panduan, dan gedung sekolah (Anton, 2012). Walaupun demikian, dinyatakan juga bahwa masalah mitigasi gempa bumi hendaknya masuk dalam kurikulum pendidikan dari jenjang SD sampai dengan SMA.

Untuk melaksanakan pelatihan MBAGB kepada siswa sekolah, para guru sekolah terlebih dahulu harus diberikan pelatihan tentang materi tersebut agar mereka mampu mentransformasikan pengetahuan dan pengalaman yang dimilikinya kepada siswa. Hal tersebut dapat dilakukan dengan pola pelatihan kepada pelatih (training of trainers) sesuai dengan kebutuhan pelaksanaan kurikulum MBAGB. Dengan model petahihan tersebut, pengetahuan dan kemampuan guru tentang MBAGB dapat ditingkatkan dan para guru dipersiapkan menjadi guru pemandu MBAGB yang secara periodik dapat memandu kegiatan MBAGB di sekolahnya masing-masing melalui kegiatan-kegiatan ekstra kurikuler. Dengan cara tersebut, kurkulum pendidikan MBAGB tidak mesti menjadi bagian kurikulum reguler sekolah yang dapat menambah beban kurikulum, tetapi dapat ditempatkan sebagai kurikulum tambahan yang dibelajarkan pada saat jeda pelaksanaan pembelajaran reguler di sekolah. Menurut Kepala Dinas Pendidikan Kabupaten Bantul, Sahari, pendidikan mitigasi bencana alam gempa bumi di SD di Daerah Istimewa Yogyakarta (DIY) tidak dijadwalkan secara khusus melainkan diberikan disela-sela mata pelajaran praktek, baik

Jurnal Pendidikan Indonesia/596 
dalam intra kurikuler maupun ekstra kurikuler (Antara News, 2010).

Keadaan sarana dan prasarana yang ada di sekolah saat ini perlu dikembangkan agar dapat berfungsi ganda, yaitu sebagai prasarana dan sarana penunjang pendidikan di sekolah dan sekaligus sebagai prasarana dan sarana untuk MBAGB. Contoh-contoh prasarana dan sarana yang dimaksud adalah sebagai berikut. Pertama halaman sekolah, setiap sekolah harus memiliki ruang kosong (halaman sekolah) yang cukup yang dapat digunakan untuk pelaksanaan kegiatan pendidikan, seperti upacara bendera dan kegiatan olahraga, yang sekaligus dapat berfungsi sebagai tempat evakuasi apabila terjadi gempa bumi. Kedua gedung sekolah, setiap gedung sekolah harus dibangun dengan konstruksi yang kuat (tahan gempa) sehingga selain berfungsi sebagai tempat belajar juga menjamin keselamatan siswa yang belajar di sekolah dari ancaman bahaya gempa bumi. Ketiga bangku dan meja belajar, setiap ruang kelas harus difasilitasi dengan bangku dan meja belajar yang memadai yang dapat berfungsi sebagai sarana belajar dan tempat berlindung para siswa apabila terjadi gempa bumi. Keempat peta evakuasi, setiap sekolah harus memiliki peta evakuasi sekolah yang menggambarkan arah evakuasi yang harus diikuti siswa ketika terjadi gempa bumi. Hal-hal tersebut diharapkan dapat meningkatkan kesiapsiagaan sekolah untuk mengantisipasi kejadian gempa bumi yang dapat terjadi sewaktu-waktu. Hal ini sesuai dengan himbauan Kementerian Pendidikan Nasional yang menghimbau seluruh pemerintah daerah menyelenggarakan pendidikan penanggunakan bencana alam di sekolah, ditengah kurangnya pengetahuan siswa terhadap bencana alam (Suara Karya, 2010).

Pada saat ini, baik prasarana maupun sarana yang tersedia di sekolah masih banyak yang belum memenuhi syarat sebagai prasarana dan sarana yang memberikan keamanan bagi siswa apabila terjadi gempa bumi. Misalnya, tidak semua sekolah memiliki halaman kosong yang cukup sebagai tempat evakuasi, bangunan gedung yang sederhana dan kurang menjamin keselamatan penghuninya, dan bangkubangku sekolah yang belum disiapkan sebagai tempat berlindung.

Di masa yang akan datang, pembangunan prasarana dan sarana pendidikan di sekolah hendaknya mempertimbangkan fungsi bangunan sebagai tempat belajar dan sekaligus sebagai tempat berlindung dari bahaya gempa bumi. Gedung-gedung sekolah hendaknya dibangun sesuai dengan standar ketahanan gempa, halaman sekolah dipersiapkan sebagai tempat evakuasi sementara, dan bangkubangku dibuat sebagai tempat berlingsung di dalam kelas. Buku panduan MBAGB dan materi pelatihan MBAGB yang dirumuskan dalam penelitian ini dapat digunakan sebagai bahan panduan pelatihan MBAGB untuk meningkatkan kepedulian siswa terhadap ancaman bahaya gempa bumi. Pelatihan MBAGB hendaknya dilakukan secara periodik agar menjadi kebiasaan bagi para siswa untuk melakukan penyelamatan diri apabila terjadi gempa.

Jurnal Pendidikan Indonesia/597 


\section{PENUTUP}

Pelatihan MBAGB kepada siswa SD, khususnya yang berada di daerah rawan bencana, merupakan sebuah keniscayaan yang harus dilakukan. Melalui pelatihan MBAGB, pengetahuan dan keterampilan siswa tentang MBAGB dapat ditingkatkan. Hal tersebut merupakan modal sosial pemerintah dalam menghadapai ancaman gempa bumi yang kejadiannya belum bisa diramalkan. Kesadaran, kepedulian, kesiapan, dan kesigapan masyarakat, khsusnya bagi mereka yang tinggal di daerah lingkaran api (ring of fire) terhadap ancaman gempa bumi perlu terus ditingkatkan.

\section{DAFTAR PUSTAKA}

Anton, W. 2012. Pakar: Mitigasi Bencana Masuk Kurikulum Pendidikan. http://www.aktual. co/sosial /144525pakar-mitigasibencana-masuk-kurikulum-

pendidikan. Diunduh 16 Juni 2013.

Antara News. 2010. Pendidikan Penanggulangan Bencana di Sekolah DIY. http://www. antaranews.com/berita/233563/pe ndidikan-penanggulanganbencana-di-sekolah-diy. Diunduh 16 Juni 2013.

Departemen Energi dan Sumber Daya Mineral (tt). Pengenalan
Gempabumi. Vulcanological Survey of Indonesia (VSI)

Joko Martono. 2011. Mitigasi Bancana dalam Perspektif Komunikasi Berkearifan Lokal. Artikel kompasiana http://sosbud.kompasiana.com.

Lilik Kurniawa, Ridwan Yunus, Mohd. Robi Amri, dan Narwawi Pramudiarta. 2011. Indek Rawan Bencana Indonesia. Badang Nasional Penanggulangan Bencana (BNPB).

Suara Karya. 2010. Selenggarakan Penanggunalan Bencana di sekolah. http://www. suarakaryaonline.com/news. html?id=258643. Diunduh 16 Juni 2013.

Subagia, I Wayan dan I G.L. Wiratma. 2013. Mitigasi Bencana Alam Gempa Bumi. Makalah. Disampaikan dalam Seminar Nasional Research Inovatif (Senari-1) yang dilaksanakan oleh Lembaga Penelitian UNDIKSHA.

Subagia, I Wayan dan I G. L. Wiratma. 2012. Kurikulum Mitigasi Bencana Alam Gempa Bumi Berbasis Kearifan Lokal Masyarakat Bali. Makalah. Disampaikan dalam Seminar Nasional FMIPA UNDIKSHA.

Subagia, I Wayan, I G. L. Wiratma, dan I Ketut Sudita. 2014. Materi Pelatihan Mitigasi Bencana Alam Gempa Bumi Berbasis Kearifan Lokal Masyarakat Bali. Singaraja: Undiksha Press. 